\title{
Peningkatan Ketebalan Miokardium Mencit (Mus musculus L.) Akibat Paparan Medan Listrik Tegangan Tinggi
}

\author{
Hendri Busman, ${ }^{1}$ Muhartono ${ }^{2}$ \\ ${ }^{1}$ Jurusan Biologi Fakultas Matematika dan Ilmu Pengetahuan Universitas Lampung, ${ }^{2}$ Bagian \\ Patologi Anatomi Fakultas Kedokteran Universitas Lampung
}

\begin{abstract}
Abstrak
Pembangunan saluran transmisi listrik tegangan tinggi diduga dapat merugikan manusia atau makhluk hidup lain. Tujuan penelitian untuk mengetahui pengaruh paparan medan listrik tegangan tinggi pada ketebalan miokardium ventrikel kiri mencit jantan (Mus musculus L.). Penelitian dilaksanakan di Laboratorium Zoologi Fakultas Matematika dan Ilmu Pengetahuan Alam Universitas Lampung serta Laboratorium Patologi Balai Penyidikan dan Pengujian Veteriner Regional III Bandar Lampung, pada bulan Juni-November 2011.Penelitian menggunakan rancangan acak lengkap dengan 4 perlakuan, ulangan 6 kali, dan dibagi dalam empat kelompok. Kelompok kontrol (K) tidak diberi perlakuan, kelompok 1 (P1) diberi paparan $5 \mathrm{kV} / \mathrm{m}$, kelompok 2 (P2) diberi paparan $6 \mathrm{kV} / \mathrm{m}$, dan kelompok 3 (P3) diberi paparan $7 \mathrm{kV} / \mathrm{m}$, masing-masing 8 jam/hari selama 37 hari. Data dianalisis menggunakan analysis of variance. Hasil penelitian didapatkan ketebalan miokardium ventrikel kiri mencit jantan pada $\mathrm{K}$

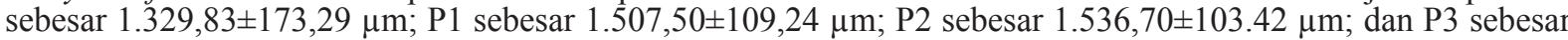
$1.574 .23 \pm 123,36 \mu \mathrm{m}$. Terdapat peningkatan ketebalan miokardium rata-rata dengan bertambahnya daya paparan medan listrik $(p=0,019)$. Simpulan, terdapat hubungan antara paparan medan listrik tegangan tinggi dan perubahan ukuran ketebalan miokardium ventrikel kiri mencit jantan, semakin tinggi paparan medan listrik semakin tebal miokardium ventrikel kiri mencit jantan. [MKB. 2013;45(3):155-60]
\end{abstract}

Kata kunci: Jantung, medan listrik, mencit jantan

\section{Increased Thickness Myocardium Mice (Mus musculus L.) Caused by Exposure to High Voltage Electric Field}

\begin{abstract}
Development of high voltage power transmission line could be expected to harm humans or other living creatures. Research objective was to determine the effect of exposure tohigh-voltage electric field to the thickness of the left ventricular myocardium male mice (Mus musculus L.). The experiment was conducted at the Laboratory of Zoology Faculty of Mathematics and Natural Sciencesat the University of Lampung and Central Pathology Laboratory Regional Veterinary Investigation III Bandar Lampung, in June-November 2011. Research using completely randomized design with 4 treatments, replicated 6 times and divided into four groups. The control group $(\mathrm{K})$ was not given treatment, group $1(\mathrm{P} 1)$ given exposure to $5 \mathrm{kV} / \mathrm{m}$, group $2(\mathrm{P} 2)$ given exposure to $6 \mathrm{kV} /$ mand group 3 (P3) given exposure to $7 \mathrm{kV} / \mathrm{m}$ for 8 hours/day, to 37 days. Data were analyzed using analysis of variance. The results obtained thickness of the left ventricular myocardium of male mice at K1,329.83 \pm 173.29 $\mu \mathrm{m} ; \mathrm{P} 1$ at $1,507.50 \pm 109.24 \mu \mathrm{m} ; \mathrm{P} 2$ at $1,536.70 \pm 103.42 \mu \mathrm{m}$, and P3 at 1,574.23 $\pm 123.36 \mu \mathrm{m}$. There was an increase in the average thickness of the myocardium with increasing exposure to power an electric field with a statistical test obtained $(p=0.019)$. In conclusion, there is a significant relationship between exposure to high-voltage electric field to change the size of the thickness of the left ventricular myocardium male mice, the higher the electric field exposure thicker left ventricular myocardium male mice. [MKB. 2013;45(3):155-60]
\end{abstract}

Key words: Electrical field, heart, male mice

Korespondensi: Muhartono, S.Ked, dr., M.Kes, Sp.PA, Fakultas Kedokteran Universitas Lampung Jl. Soemantri Brojonegoro No 1 Bandar Lampung, mobile 081272358340,e-mail: dmuhartono@yahoo.com 


\section{Pendahuluan}

Secara alami terdapat kedekatan manusia dengan medan listrik. Hal tersebut disebabkan medan listrik sudah ada sejak bumi kita terbentuk. Awan yang mengandung potensial air memiliki medan listrik. Demikian pula bumi secara alamiah bermedan listrik. ${ }^{1}$ Pada kehidupan modern dewasa ini, peralatan listrik makin banyak digunakan oleh manusia untuk memperoleh kemudahan. Laju pertumbuhan konsumsi tenaga listrik di Indonesia ternyata di atas angka rata-rata di Asia Timur yaitu sekitar $7,9 \%$ per tahun dan jauh di atas rata-rata pertumbuhan konsumsi tenaga listrik dunia yang berkisar 3,6\% per tahun. ${ }^{2}$

Produk listrik (radiasi) tersebut mempunyai pengaruh biologis yang merusak dan merugikan manusia dan juga makhluk lain. Secara teoritis radiasi listrik menganggu kesehatan jika melebihi ambang batas. Angka yang dikeluarkan oleh International Radiation Protection Association (IRPA) dan World Health Organization (WHO) tentang batasan paparan kuat medan listrik yang diduga dapat menimbulkan efek biologis yaitu 5 $\mathrm{kV} / \mathrm{m}^{1}$

Potensi gangguan kesehatan yang terjadi oleh paparan medan listrik dapat terjadi pada berbagai macam sistem tubuh, antara lain sistem darah, reproduksi, kardiovaskular, endokrin, psikologis, saraf, dan juga sistem imun (hipersensitivitas). Manifestasi hipersensitivitas dikenal pula dengan istilah electrical sensitivity yang menggambarkan gangguan fisiologis berupa tanda dan gejala neurologis maupun kepekaan terhadap medan elektromagnetik dengan gejala-gejala yang khas. ${ }^{3}$ Hasil penelitian menunjukkan bahwa paparan medan listrik menahun mampu menyebabkan gejala, seperti mudah lelah, sakit kepala, mudah marah, mengantuk selama bekerja, penurunan kepekaan indra penciuman, ketegangan mata, sulit tidur, suka murung, kurang ramah, perasaan takut, ketegangan saraf, ingatan terganggu, nyeri pada otot dan daerah jantung, banyak keringat, neurasthenia, iritabilitas, problem konsentrasi, dan juga kesulitan dalam kehidupan seksual. Pemeriksaan fisis memperlihatkan bradikardia, hipotensi, hipertiroid, dan peningkatan kadar histamin darah. ${ }^{4}$

Investigasi yang lebih baru telah berfokus terutama efek langsung paparan medan listrik terhadap jantung, terutama yang berkaitan dengan variabilitas detak jantung dan pengaruhnya pada kejadian kardiovaskular akut lainnya. ${ }^{5}$ Selain itu, penelitian oleh Mohamed dkk. ${ }^{6}$ mengenai efek paparan medan listrik yang dilakukan terhadap tikus menunjukkan peningkatan tekanan darah sistol serta ditemukan hipertrofi, fragmentasi, dan vakuolasi miokardium tikus yang mendapat paparan selama 3 (tiga) jam/hari dalam waktu empat minggu. Paparan aliran arus listrik pada tubuh manusia tampaknya berperan untuk dapat menghasilkan efek utama sistem kardiovaskular. Kebanyakan penelitian tentang efek medan listrik pada sistem kardiovaskular telah difokuskan pada efek akut daripada jangka panjang, namun penelitian efek medan listrik sampai sekarang masih terus diperdebatkan dan terus mengalami perkembangan. ${ }^{5}$

Jantung merupakan organ tubuh manusia yang sangat berperan dalam sistem keseimbangan pasokan darah di dalam tubuh. Mekanisme ini dimungkinkan oleh karena perubahan potensial listrik pada pacu jantung dan secara berurutan akan tersebar melalui sistem hantaran ke seluruh bagian jantung. ${ }^{7}$ Jantung terdiri atas jaringan yang mempunyai sifat kelistrikan yang tinggi. Berbeda dengan sel saraf dan otot rangka yang membrannya tetap berada pada potensial istirahat yang konstan kecuali apabila dirangsang, sel otot ritmik jantung tidak memiliki potensial istirahat. Otot jantung merupakan sel kontraktif yang berkerja secara mekanis dan berkontraksi karena rangsangan yang dicetuskan oleh sel lainnya yang bersifat sebagai pemacu atau pacemaker. Sel-sel ini mampu menghasilkan sendiri potensial aksi yang selanjutnya disebarkan ke seluruh bagian jantung. ${ }^{8}$

Penyebab kematian terbesar akibat sengatan listrik oleh karena terjadi henti jantung, sehingga akan memberikan gambaran mikroskopis yang khas pada otot jantung. Setelah masuk ke dalam tubuh, listrik akan keluar tubuh melalui sisi kontralateral, sehingga listrik akan melewati jantung. Sengatan listrik yang melewati jantung akan mengganggu sistem kelistrikan jantung dan energi panas yang ditimbulkannya akan merusak miokardium. Keadaan ini ditandai dengan fibrilasi dan asistol ventrikel yang akhirnya menganggu aliran darah ke seluruh tubuh. Penelitian ini diharapkan dapat memberikan informasi dalam mengidentifikasi korban trauma sengatan listrik, sehingga dapat merupakan kebaruan (novelty) pada pengembangan penelitian.

Berdasarkan hal di atas, peneliti bermaksud mengetahui pengaruh paparan medan listrik bertegangan tinggi terhadap ukuran ketebalan miokardium ventrikel hewan mencit jantan (Mus musculus L.).

\section{Metode}

Penelitian merupakan uji eksperimental dengan menggunakan desain rancangan acak lengkap, dilaksanakan di Laboratorium Zoologi Fakultas Matematika dan Ilmu Pengetahuan Alam (MIPA) 
Universitas Lampung dan Laboratorium Patologi Balai Penyidikan dan Pengujian Veteriner (BPPV) Regional III Bandar Lampung pada bulan JuniNovember 2011.

Penelitian ini menggunakan mencit jantan (Mus musculus L.) yang diperoleh dari Fakultas Peternakan Institut Pertanian Bogor. Kriteria sampel adalah mencit jantan sehat, berusia 3-4 bulan, memiliki bobot 30-40 gram. Penelitian ini terdiri atas 4 kelompok perlakuan. Jumlah mencit ditentukan dengan menggunakan Rumus Frederer, yaitu (t-1)(n-1) $\geq 15$, dengan nilai $t$ merupakan jumlah perlakuan dan nilai $n$ merupakan jumlah ulangan serta besar sampel.

Alat yang digunakan pada penelitian ini antara lain kandang hewan uji (mencit), lempeng logam elektroda yang digunakan untuk mengalirkan arus medan listrik, electric power supply yang digunakan untuk mengatur arus medan listrik, botol spesimen yang digunakan untuk menyimpan spesimen, alat bedah yang digunakan dalam proses pemotongan jaringan, mikrotom geser yang digunakan untuk memotong jaringan, pan, lampu gas, oven, kuas, stik berujung runcing, mikrotom geser, balok kayu $(3 \times 2 \mathrm{~cm})$, embedding casette, staining jar, refrigator, stopwatch, water bath, cover glass, object glass, dan mikroskop.

Bahan yang dipergunakan dalam penelitian ini adalah organ tubuh mencit jantan, aluminium foil, kertas saring, kapas, tisu, bufer formalin, akuades, alkohol 80\%, alkohol 95\%, alkohol 96\%, alkohol absolut, xilol, parafin, pewarna harris, hematoxylin eosin, acid alcohol, dan pelet ayam sebagai makanan mencit.

Perlakuan dilakukan terhadap tiap kelompok 8 jam per hari selama 37 hari dengan rincian perlakuan sebagai berikut: kelompok kontrol (K), yaitu pada kelompok Mus musculus L. yang tidak diberikan paparan medan listrik. Kelompok perlakuan 1 (P1), yaitu kelompok Mus musculus L. yang diberi paparan medan listrik $5 \mathrm{kV} / \mathrm{m}$. Kelompok perlakuan 2 (P2), yaitu kelompok Mus musculus L. yang diberi paparan medan listrik $6 \mathrm{kV} / \mathrm{m}$. Kelompok perlakuan 3 (P3), yaitu kelompok Mus musculus L. yang diberi paparan medan listrik $7 \mathrm{kV} / \mathrm{m}$.

Setelah mencit diberi perlakuan selama 37 hari (selama periode siklus spermatogenesis mencit jantan), pada hari ke-38 mencit tersebut dilakukan pembiusan mempergunakan kloroform serta pembedahan dan diambil organ jantungnya. Jantung yang telah diambil segera dilakukan fiksasi dengan larutan formalin $10 \%$. Prosedur organ pembuatan preparat histologi jantung yang dilakukan meliputi fiksasi, trimming, dehidrasi, clearing, impregnasi, embedding, cutting, lalu staining, dan mounting. Parameter yang diamati berupa perubahan ukuran ketebalan miokardium pada ventrikel kiri. Ketebalan miokardium dalam hal ini terkait dengan hipertropi, karena parameter yang diamati adalah ukuran miokardium yang secara histologi merupakan komponen miofibril dalam fungsi kontraktil otot jantung.

Data yang diperoleh dalam penelitian ini merupakan data primer, yaitu data yang diperoleh langsung dari sumber. Data yang diperoleh diolah secara statistik dengan menggunakan program statistical product and service solution (SPSS) versi 16.0 for Windows. Untuk mengetahui ada tidaknya perbedaan efek yang ditimbulkan antar perlakuan, data diolah dengan mempergunakan analisis varians (analysis of variance, ANOVA). Apabila terdapat perbedaan nyata, dilanjutkan dengan uji beda nyata terkecil (BNT) pada derajat kepercayaan $5 \%,{ }^{9}$ serta analisis post hoc least significant difference (LSD) untuk menilai perbedaan masing-masing kelompok.

\section{Hasil}

Penelitian yang dilakukan terhadap mencit yang diberikan paparan medan listrik tegangan tinggi sebesar $5 \mathrm{kV} / \mathrm{m}, 6 \mathrm{kV} / \mathrm{m}, 7 \mathrm{kV} / \mathrm{m}$, serta tanpa paparan medan listrik didapatkan hasil yang bervariasi pada ketebalan miokardium mencit.

Pada kelompok K, P1, P2, dan P3 didapatkan ukuran ketebalan miokardium rata-rata berturutturut $1.329,83 \pm 173,29 \mu \mathrm{m}, 1.507,50 \pm 109,24 \mu \mathrm{m}$, $1.536,70 \pm 103,42 \mu \mathrm{m}$, dan $1.574,23 \pm 123,39 \mu \mathrm{m}$ (Tabel 1).

Ukuran ketebalan miokardium ventrikel kiri diuji normalitasnya dengan Uji Saphiro-Wilk dan didapatkan distribusi data normal $(p>0,05)$. Hasil uji varians didapatkan nilai $\mathrm{p}=0,437$; maka dapat diambil kesimpulan bahwa varians data adalah sama. Syarat uji parametrik terpenuhi, sehingga dapat dilanjutkan dengan uji ANOVA, diperoleh nilai $\mathrm{p}=0,019$; artinya terdapat perbedaan yang bermakna pada kedua kelompok. Berdasarkan analisis dengan memakai uji oneway ANOVA diketahui bahwa terdapat pengaruh pemberian

\begin{tabular}{cc}
$\begin{array}{c}\text { Tabel } 1 \text { Ukuran dan Standar Deviasi } \\
\text { Ketebalan Miokardium Rata-rata } \\
\text { Ventrikel Kiri ( } \boldsymbol{\mu m}) \text { pada Kelompok } \\
\text { Kontrol dan 3 Kelompok Perlakuan }\end{array}$ \\
\hline Kelompok Perlakuan & Mean+SD \\
\hline K & $1.329,83 \pm 173,29$ \\
P1 & $1.507,50 \pm 103,42$ \\
P2 & $1.536,70 \pm 103,42$ \\
P3 & $1.574,23 \pm 123,39$ \\
\hline
\end{tabular}


Tabel 2 Hasil Uji Statistik Perbandingan antar Kelompok (Analisis Post Hoc LSD)

\begin{tabular}{lcccc}
\hline \multicolumn{1}{c}{ Kelompok } & $\mathbf{K}$ & $\mathbf{P 1}$ & $\mathbf{P 2}$ & P3 \\
\hline K & - & $0,028^{*}$ & $0,012^{*}$ & $0,004^{*}$ \\
P1 & 0,702 & - & 0,385 & $0,012^{*}$ \\
P2 & $0,012^{*}$ & 0,720 & - & 0,623 \\
P3 & $0,004^{*}$ & 0,385 & 0,623 & - \\
\hline
\end{tabular}

*Hasil analisis post hoc bermakna jika $\mathrm{p}<0,05$

paparan medan listrik tegangan tinggi terhadap ukuran ketebalan miokardium ventrikel kiri yang signifikan $(\mathrm{p}<0,05)$.

Kelompok perlakuan 1 mempunyai $\mathrm{p}=0,702$; perlakuan 2 dan perlakuan 3 dengan $\mathrm{p}=0,385$. Kelompok perlakuan 1 dengan perlakuan 2 tidak memiliki perbedaan signifikan, begitu juga antara perlakuan 1 dan perlakuan 3. Keadaan yang sama juga terlihat antara perlakuan 2 dan perlakuan 3 $(\mathrm{p}=0,623$; Tabel 2).

Analisis data dilanjutkan dengan memakai analisis post hoc least significant difference (LSD) untuk menilai perbedaan masing-masing kelompok. Dari analisis post hoc LSD terdapat perbedaan bermakna antara kelompok kontrol dan paparan $5 \mathrm{kV} / \mathrm{m}$, antara kontrol dan paparan $6 \mathrm{kV} / \mathrm{m}$, juga antara kontrol dan paparan $7 \mathrm{kV} / \mathrm{m}$, sedangkan antara paparan $5 \mathrm{kV} / \mathrm{m}$ dan $6 \mathrm{kV} / \mathrm{m}$, antara paparan $5 \mathrm{kV} / \mathrm{m}$ dan $7 \mathrm{kV} / \mathrm{m}$, serta antara paparan $6 \mathrm{kV} / \mathrm{m}$ dan $7 \mathrm{kV} / \mathrm{m}$ tidak berbeda bermakna.
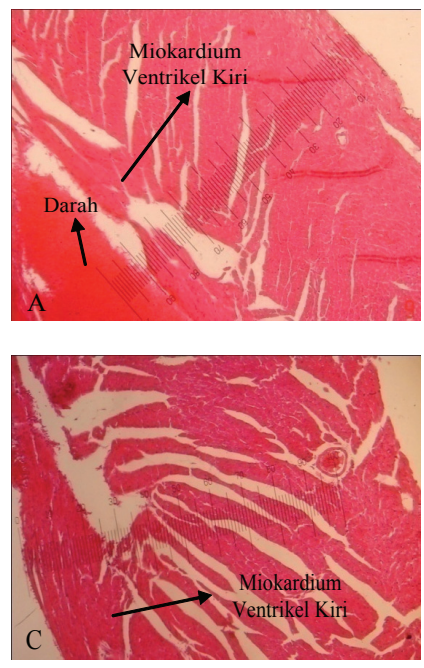
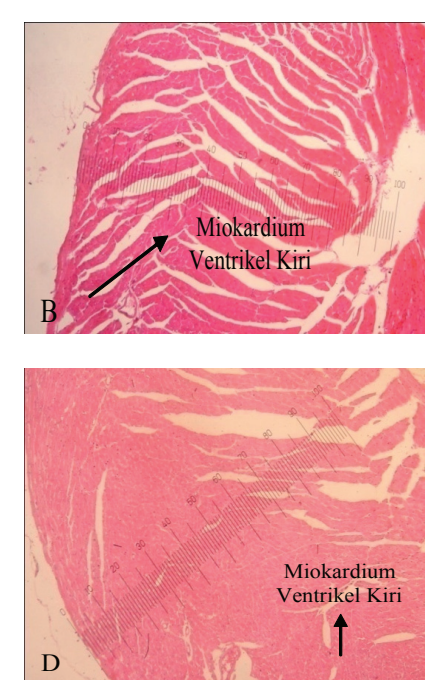

\section{Pembahasan}

Pengaruh paparan medan listrik bertegangan tinggi sampai saat ini masih terus dipelajari dan dikembangkan. Potensi pada gangguan kesehatan yang timbul akibat paparan medan litrik tegangan tinggi dapat terjadi pada berbagai sistem tubuh yang salah satunya pada sistem kardiovaskular. ${ }^{3}$ Jantung terdiri atas jaringan yang mempunyai sifat kelistrikan yang tinggi. Kurang lebih 99\% otot jantung (miokardium) adalah sel kontraktif yang berkontraksi.?

Terdapat peningkatan ketebalan miokardium rata-rata dimulai dari kelompok kontrol sampai dengan kelompok perlakuan 3. Setelah dilakukan uji one way ANOVA didapatkan $\mathrm{p}=0,019$. Hal ini menunjukkan terdapat pengaruh bermakna pemberian perlakuan terhadap ukuran ketebalan miokardium ventrikel kiri mencit jantan.

Dilakukan uji post hoc LSD untuk melihat kelompok mana yang menunjukkan perubahan

Gambar Gambaran Histologi Perbedaan Ketebalan Miokardium Ventrikel Kiri Mencit Jantan (Pembesaran100x) A. Kontrol (K); B. Paparan 5 kV/m (P1); C. Paparan 6 kV/m (P2); D. Paparan 7 kV/m (P3) 
ukuran ketebalan miokardium paling bermakna. Berdasarkan hasil uji post hoc LSD, pada kelompok kontrol dengan perlakuan $1,2,3$, nilai $\mathrm{p}<0,05$ artinya terdapat perbedaan yang signifikan ukuran ketebalan miokardium antara kelompok kontrol dan lainnya. Hal ini berarti variasi tegangan listrik yang digunakan pada perlakuan 2 dan 3 belum sejalan dengan perubahan ukuran ketebalan miokardium ventrikel kiri mencit.

Dari hasil pengamatan secara mikroskopis dan analisis data yang telah dilakukan, didapatkan paparan medan listrik tegangan tinggi memiliki pengaruh pada ukuran ketebalan miokardium ventrikel kiri mencit jantan (Mus musculus L.).

Peningkatan ukuran ketebalan miokardium ventrikel kiri ini dapat diakibatkan oleh pengaruh paparan medan listrik yang dapat menimbulkan kompensasi berupa penebalan dinding jantung. Hal ini sesuai dengan teori yang dikemukakan oleh WHO dan IRPA yang menyatakan bahwa salah satu efek medan listrik bertegangan tinggi yang melewati nilai ambang batas toleransi dapat menganggu kesehatan, salah satunya gangguan pada sistem kardiovaskular. ${ }^{1}$

Paparan medan elektromagnetik berpengaruh terhadap peningkatan denyut jantung, respirasi, tekanan darah, denyut nadi, serta suhu tubuh. Paparan medan magnet dan listrik menimbulkan efek pada jantung dapat melalui berbagai proses, antara lain mengubah irama eksitasi dengan cara memengaruhi nodus sinoatrial yang merupakan sel pacemaker, mencetuskan fokus ektopik pada sel yang seharusnya tidak teraktivasi, dan menyebabkan aritmia dengan mengubah pola potensial aksi miokardium (efek depolarisasi dan hiperpolarisasi). Proses aritmia yang dicetuskan oleh medan listrik tersebut akan menyebabkan mekanisme kompensasi jantung yang akhirnya dapat menimbulkan penebalan dinding jantung. ${ }^{5}$

Terdapat teori lainnya mengenai bagaimana paparan medan listrik dapat memberikan efek pada tubuh, namun masih belum jelas mekanisme pasti mengenai teori tersebut. Salah satu teori mengenai berinteraksinya tubuh manusia terhadap medan listrik memperlihatkan bahwa interaksi tersebut mampu menginduksi arus listrik, yang terlihat pada studi laboratorium dan perhitungan teori bahwa densitas yang tinggi dari arus listrik internal akan menyebabkan efek biologis akut. ${ }^{10}$ Teori yang dikemukakan oleh Milgram dkk. ${ }^{11}$ memprediksikan bahwa paparan elektromagnetik akan memacu interkonversi dari singlet menjadi triplet dan menaikkan proporsi triplet serta kadar radikal bebas dalam tubuh yang bersifat sangat reaktif dan mutagenik.

Proses kerusakan yang terjadi pada tingkat selular diduga dapat diakibatkan oleh peningkatan ukuran ketebalan miokardium. Menurut laporan
Kennedy dkk., ${ }^{12}$ mekanisme medan listrik dapat merusak sel melalui proses elektroporasi. Proses energi listrik merusak otot jantung melalui proses elektroporasi, panas (joule heating), denaturasi protein, dan hiperkontraksi otot rangka. Jika terpapar medan listrik yang sangat besar maka proses joule heating akan mendominasi proses kerusakan membran sel. ${ }^{13}$

Elektroporasi merupakan pembentukan kanal hidrofilik pada membran sel akibat paparan arus listrik tegangan tinggi selama beberapa detik sehingga mengakibatkan hilangnya permeabilitas membran sel terhadap ion dan molekul yang larut dalam air. Lubang pada membran sel tersebut mengakibatkan materi intraselular keluar sel dan mengganggu fungsi sel. ${ }^{13}$ Muatan listrik bebas menghasilkan suatu gaya yang akan memengaruhi ion bermuatan di dalam tubuh dan akan mengubah pola potensial aksi membran sel-sel. Perubahan yang terjadi akan menyebabkan cedera dan juga mengganggu fungsi membran sel. ${ }^{12}$ Membran sel yang mengalami cedera menyebabkan membran sel tidak mampu memompa ion natrium yang cukup, dengan demikian kenaikan konsentrasi natrium dalam sel menarik air masuk ke dalam sel. Mekanisme ini yang diduga dapat merusak otot jantung dan dapat bermanifestasi pada perubahan ukuran ketebalan sel miokardium. Peningkatan ukuran ketebalan diduga sebagai suatu bentuk hipertrofi miokardium jantung. Hipertrofi otot jantung sering dikaitkan sebagai prognosis yang buruk. Hipertrofi patologis biasanya berhubungan dengan regulasi genetik yang buruk, fibrosis, dan disfungsi otot jantung.

Simpulan, terdapat hubungan paparan medan listrik bertegangan tinggi dengan ukuran ketebalan miokardium ventrikel hewan mencit jantan (Mus musculus L.). Disarankan dilakukan penelitian lebih lanjut untuk pengamatan histologi ruangan jantung lain, seperti miokardium ventrikel kanan, atrium kiri, dan atrium kanan secara lengkap.

\section{Daftar Pustaka}

1. Crumpton MJ. The bernal lecture 2004 Arelow-frequency electromagnetic fields a health hazard? Philos Trans R Soc Land B Biol Sci. 2005;360(1458):1223-30.

2. Torres-Duran PV, Ferreira-Hermosillo A, Juarez-Oropeza MA, Elias-Vinas D, Verdugo-Diaz L. Effects of whole body exposure to extremely low frequency electromagnetic fields (ELF-EMF) on serum and liver lipid levels, in the rat. Lipids Health Dis. 2007;6:31-5.

3. Anies. Pengendalian dampak kesehatan akibat radiasi medan elektromagnetik. Media 
Medika Indonesia. 2003;38(4):213-9.

4. Hardjono H, Qadrijati I. Pengaruh paparan medan elektromagnetik terhadap kecemasan penduduk. Nexus Medicus. 2004;16:68-78.

5. Rubin GJ, Das Munshi J, Wessely S. Electromagnetic hypersensitivity: a systematic review of provocation studies. Psychosom Med. 2005;67(2):224-32.

6. Mohamed FA, Ahmed AA, El-Kafoury BMA, Lasheen NN. Study of the cardiovascular effects of exposure to electromagnetic field. Life Science J. 2011;8(1):260-74.

7. Fineschi V, Karch SB, D'Errico S, Pomara C, Riezzo I, Turillazzi E. Cardiac pathology in death from electrocution. Int J Legal Med. 2006;120(2):79-82.

8. Huss A, Roosli M. Consultations in primary care for symptoms attributed to electromagnetic fields-a survey among general practitioners. BMC Public Health. 2006;6:267.

9. Notoatmodjo S. Metodologi penelitian kesehatan. Jakarta: Rineka Cipta; 2010.

10. Ahlbom A. Feychting M. Electromagnetic radiation. Br Med Bull. 2003;68:157-65.

11. Milgram J, Shahar R, Levin-Harrus T, Kass P. The effect of short, high intensity magnetic field pulses on the healing of skin wounds in rats. Bioelectromagnetics. 2004;25(4):271-7.

12. Kennedy SM, Hedstrom JC, Booske $\mathrm{JH}$, Hagness SC. Quantification of electroporative uptake kinetics and electric field heterogenity effect in cells. Biophys J. 2008;94(12):5018-27.

13. Dzhokic G, Jovchevska J, Dika A. Electrical injuries: etiology, pathophysiology and mechanism of injury. Maced $\mathrm{J}$ Med Sci. 2008;1(2):54-9. 